\title{
Ophthalmic Manifestations of HIV Patients in a Rural Area of Western Maharashtra, India
}

\author{
Pratik Y. Gogri, ${ }^{1,2}$ Somen L. Misra, ${ }^{2}$ Raghunandan N. Kothari, ${ }^{3}$ \\ Akshay J. Bhandari, ${ }^{2}$ and Hitesh V. Gidwani ${ }^{4}$ \\ ${ }^{1}$ Department of Ophthalmology, Rural Medical College and Pravara Rural Hospital of Pravara Institute of Medical Sciences, \\ Loni, Ahmednagar, Maharashtra 413736, India \\ ${ }^{2}$ Department of Ophthalmology, Pravara Institute of Medical Sciences, Loni, Maharashtra 413736, India \\ ${ }^{3}$ Department of Ophthalmology, Smt. B. K. Shah Medical Institute \& Research Centre, Vadodara, Gujarat 391750, India \\ ${ }^{4}$ Department of Medicine, UPMC Mercy, Pittsburgh, PA 15219, USA
}

Correspondence should be addressed to Pratik Y. Gogri; pratikgogri@yahoo.com

Received 24 July 2014; Revised 1 October 2014; Accepted 21 October 2014; Published 11 November 2014

Academic Editor: Tao-Hsin Tung

Copyright (C) 2014 Pratik Y. Gogri et al. This is an open access article distributed under the Creative Commons Attribution License, which permits unrestricted use, distribution, and reproduction in any medium, provided the original work is properly cited.

Introduction. HIV/AIDS is one of twenty first century's biggest global challenges to mankind with protean manifestations affecting all organs of our body, not even sparing the eyes. The purpose of this study was to determine the pattern of ocular manifestations of HIV/AIDS and their correlation with CD4-count in a rural area of India. Methods. A hospital based observational cross-sectional study was done on $40 \mathrm{HIV}$-positive patients presenting to ART center with ocular complaints. Data were collected using face-toface interview, clinical examination, slit lamp examination, fundus examination, and laboratory investigations. Results. Out of 40 patients, 21 were males and 19 were females with mean age of $38.75 \pm 13.9$ years. HIV retinopathy was the most common HIVassociated ophthalmic lesion while anterior uveitis was the most common anterior segment finding. Posterior segment lesions showed significant association $(P<0.05)$ with low CD4-count of the patient. CMV retinitis, retinal detachment, tubercular chorioretinitis, and acute retinal necrosis were all seen in patients with CD4-count less than 100 cells $/ \mathrm{mm}^{3}$. Conclusions. HIV retinopathy, CMV retinitis, herpes zoster ophthalmicus, and anterior uveitis are common ocular manifestations associated with HIV infection. Low CD4-count is a risk as well as predictor for ocular manifestations. There needs to be awareness of ocular involvement among HIV infected individuals and an increased emphasis on regular ophthalmic examination.

\section{Introduction}

Since the report of an unusual occurrence of Pneumocystis carinii pneumonia in five cases on June 5,1981 , by Gottlieb and colleagues (Pneumocystis pneumonia-Los Angeles), which was probably the first publication on this infection, a great collection of literature has accumulated regarding this devastating illness [1]. In the 30 years, since the appearance of that article, human immunodeficiency virus (HIV), the causative agent of acquired immune deficiency syndrome (AIDS), has been identified and has reached virtually every corner of the globe, emerging as the most challenging pandemic of our time. It appears to be omnipresent, with the manifestations sparing no organ.

Among HIV-positive individuals, the lifetime cumulative risk for developing at least one abnormal ocular lesion ranges from $52 \%$ to $100 \%$ in various studies [2]. Such lesions are varied and affect almost any structure of the eye. Ocular lesions usually occur in the late phase of HIV infection but can also be the presenting manifestation of the disease. Various ocular manifestations-including cytomegalovirus (CMV) retinitis, toxoplasma retinochoroiditis, ocular tuberculosis, and toxoplasma retinochoroiditis-are considered to be AIDS-defining conditions.

Since it was first described in 1981, AIDS has become a major concern to all doctors, irrespective of their area of study or specialization. Even the ophthalmologists have not been spared. They sometimes make the initial diagnosis of AIDS; most often, however, they are requested to help treat the ocular manifestation related opportunistic infection. These can have disastrous consequences for sight, especially for 
patient who are first seen when already markedly debilitated. Ophthalmologists are faced with the challenge to recognize and treat potentially sight threatening conditions and to identify unusual presentations. They are sometimes first to diagnose the disease based on suspicious ocular clinical presentation of patients. If these ocular manifestations are detected at an early stage and treated promptly, it will be helpful to prevent or minimize consequent visual damage.

As part of our efforts to provide best of care to HIV patients, prevention of visual morbidity in these patients because of ocular complications also needs to be addressed. Information regarding these ocular manifestations is unavailable from a rural area of India. Till date, to the best of our knowledge, there has been no study indicating the ocular manifestations of HIV/AIDS from a rural area of India. Hence, this study was undertaken to identify the ocular manifestations of HIV/AIDS in a rural area of western Maharashtra in India.

\section{Methods}

2.1. Study Design. The present study was a hospital based observational cross-sectional study carried out at the Department of Ophthalmology of Rural Medical College and Pravara Rural Hospital of Pravara Institute of Medical Sciences, Loni, from the period of August 2011 to August 2013 (2 years). The hospital has an ART center affiliated to National AIDS Control Organisation (NACO) and catering to around 260 villages in the region.

2.2. Inclusion Criteria. HIV-positive patients registered at the ART centre and referred to Ophthalmology OPD for ocular complaints were included in the study. Patients presenting to ophthalmology OPD directly who were not originally known to be HIV-positive and were subsequently tested for and diagnosed to be HIV-positive because of suspicious ocular lesions were also included.

2.3. Data Collection. Data was collected using interview, clinical examination, and laboratory investigations. Distance and near vision were tested using Snellen's distance and Jaeger near vision chart, respectively. Anterior segment examination was done with the help of slit lamp biomicroscope. Fundus examination with indirect ophthalmoscopy was done in all patients. Positive findings were documented on Zeiss slitlamp camera, Topcon fundus camera, and digital camera. Fundus fluorescein angiography, ultrasound examination, and other ancillary investigations such as magnetic resonance imaging and infectious agent antibody titres were obtained in cases wherever necessary. CD4-count was obtained in all cases.

2.4. Statistical Analysis. Mean and standard deviation were used as descriptive statistical tools and chi-square was used as inferential statistical tool. A comparison of all the ocular manifestations of adnexal, anterior segment, posterior segment, and neuroophthalmic lesions was done in relation to the CD4-count at presentation. To analyze the association we
TABle 1: Age-wise distribution of patients.

\begin{tabular}{lc}
\hline Age (years) & Number of patients \\
\hline $0-10$ & $3(7.5 \%)$ \\
$11-20$ & $1(2.5 \%)$ \\
$21-30$ & $5(12.5 \%)$ \\
$31-40$ & $12(30 \%)$ \\
$41-50$ & $12(30 \%)$ \\
$51-60$ & $5(12.5 \%)$ \\
$61-70$ & $2(5 \%)$ \\
Total & $\mathbf{4 0}$ \\
Mean age & $\mathbf{3 8 . 7 5} \pm \mathbf{1 3 . 9}$ years
\end{tabular}

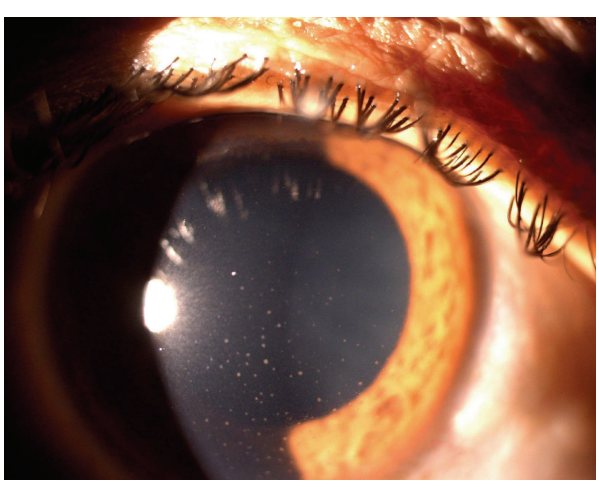

FIgure 1: Anterior uveitis.

applied Chi-square test ( $\chi^{2}$-test) to the data wherever possible and $P<0.05$ was considered significant.

2.5. Ethical Issues. This study was conducted according to the principles expressed in the Declaration of Helsinki. Ethical approval for this study was obtained from the Institutional Ethical Committee and Research Cell of Pravara Institute of Medical Sciences. A written informed consent was obtained from all patients before including them in the study and only those who consented were studied.

\section{Results}

40 HIV-positive patients with ocular complaints were included in the study. There were 21 males and 19 females. Male-to-female ratio was 1.1:1. Age of the patients ranged between 6 years and 63 years with a mean age of 38.75 years \pm 13.9 (standard deviation) (Table 1). The median age of the 40 patients was 39.5 years. Youngest patient was 6 years old and oldest was 63 years of age.

A total of 26 patients (65\%) had anterior segment lesions. 27 anterior segment lesions were found among 26 patients (Table 2). The most common anterior segment finding was anterior uveitis (5 patients, 12.5\%) (Figure 1) followed by molluscum contagiosum (Figure 2) and viral keratitis. Other lesions seen in the anterior segment were blepharitis, ocular surface squamous neoplasia (OSSN) (Figure 3), and Steven Johnson's syndrome (SJS). 
TABLE 2: Adnexal and anterior segment lesions.

\begin{tabular}{lccc}
\hline Anterior segment lesions & Number of patients & $\begin{array}{c}\text { Percentage of total patients } \\
(n=40)\end{array}$ & $\begin{array}{c}\text { Percentage of adnexal/anterior } \\
\text { segment lesions }(n=27)\end{array}$ \\
\hline Anterior uveitis & 5 & 12.5 & 18.5 \\
Molluscum contagiosum & 4 & 10 & 14.8 \\
Viral keratitis & 4 & 10 & 14.8 \\
Blepharitis & 4 & 10 & 14.8 \\
Herpes zoster ophthalmicus & 2 & 5 & 7.4 \\
Dry eyes & 3 & 7.5 & 11.1 \\
Giant papillary conjunctivitis & 2 & 5 & 7.4 \\
Ocular surface squamous neoplasia & 2 & 5 & 7.4 \\
Steven Johnson's syndrome & 1 & 2.5 & 3.7 \\
\hline
\end{tabular}

TABLE 3: Posterior segment lesions.

\begin{tabular}{llcc}
\hline Posterior segment lesions & Number of patients & $\begin{array}{c}\text { Percentage of total patients } \\
(n=40)\end{array}$ & $\begin{array}{c}\text { Percentage of posterior } \\
\text { segment lesions }(n=25)\end{array}$ \\
\hline HIV retinopathy & 7 & 17.5 & 28 \\
CMV retinitis & 5 & 12.5 & 20 \\
Toxoplasma retinochoroiditis & 3 & 7.5 & 12 \\
Retinal detachment & 3 & 7.5 & 12 \\
Retinal vascular occlusions & 2 & 5 & 8 \\
Retinopathy of anaemia & 2 & 5 & 8 \\
Tubercular chorioretinitis & 1 & 2.5 & 4 \\
Acute retinal necrosis & 1 & 2.5 & 4 \\
Endogenous endophthalmitis & 1 & 2.5 & 4 \\
\hline
\end{tabular}

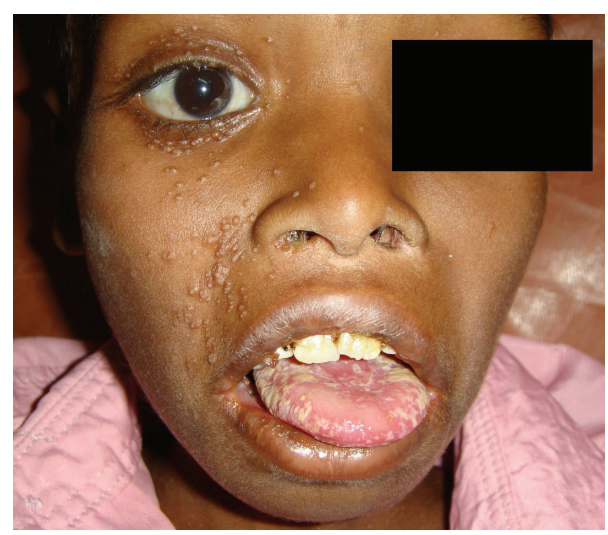

FIGURE 2: Molluscum contagiosum on right eyelids and cheek.

Out of 40 patients, 16 patients (40\%) had posterior segment lesions. A total of 25 posterior segment lesions were found among 16 patients (Table 3). Opportunistic infections of the retina and choroid were the most common posterior segment finding seen in 11 patients. CMV retinitis $(12.5 \%)$ (Figure 4) was the most common opportunistic infection of the retina/choroid followed by toxoplasmosis (Figure 5) and tuberculosis. Other lesions seen were HIV retinopathy and acute retinal necrosis (ARN) (Figure 6).

Table 4 enlists the neuroophthalmic lesions found in the study patients. 4 patients $(10 \%)$ showed neuroophthalmic

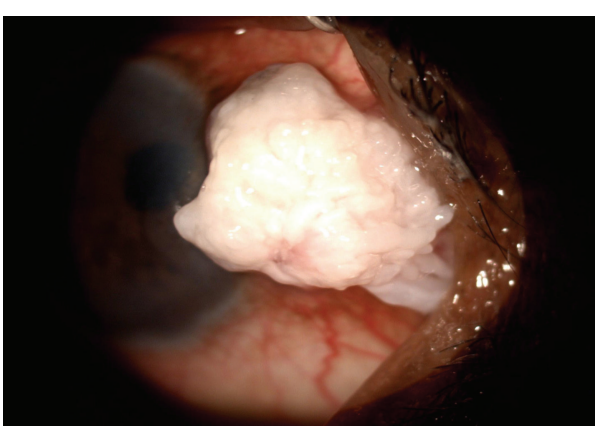

FIgURE 3: Squamous cell carcinoma of conjunctiva.

manifestations. Papilledema was the most common finding among neuroophthalmic lesions found in 2 patients. 1 patient had optic neuritis (Figure 7) while 1 patient had 3 rd cranial nerve palsy.

A total of 60 eyes had some or the other ocular lesion at presentation. Table 5 shows the best corrected visual acuity in these eyes. Based on the severity of visual impairment in the eyes with ocular lesions, the patient's eyes were divided into groups with visual acuity better than or $6 / 12$, between $6 / 18$ and $6 / 60$, and worse than $6 / 60$.

The mean CD4-counts of the patients were more of those having anterior segment lesions (mean CD4-count: 305 cells/ $\mathrm{mm}^{3}$ ) than those having posterior segment lesions (mean 
TABLE 4: Neuroophthalmic lesions.

\begin{tabular}{lccc}
\hline Neuroophthalmic lesions & Number of patients & $\begin{array}{c}\text { Percentage of total patients } \\
(n=40)\end{array}$ & $\begin{array}{c}\text { Percentage of neuroophthalmic } \\
\text { lesions }(n=4)\end{array}$ \\
\hline Papilledema & 2 & 5 & 50 \\
Optic neuritis & 1 & 2.5 & 25 \\
3rd cranial nerve palsy & 1 & 2.5 & 25 \\
\hline
\end{tabular}

TABLE 5: Visual impairment in eyes with ocular lesion/s $(n=60)$.

\begin{tabular}{|c|c|c|c|c|c|}
\hline \multirow[b]{2}{*}{ Visual acuity } & \multicolumn{4}{|c|}{ Segment of eye involved } & \multirow[b]{2}{*}{ Total } \\
\hline & $\begin{array}{l}\text { Only adnexal and } \\
\text { anterior segment }\end{array}$ & $\begin{array}{l}\text { Only posterior } \\
\text { segment }\end{array}$ & $\begin{array}{c}\text { Only neuroophthalmic } \\
\text { lesions }\end{array}$ & $\begin{array}{l}\text { Combination of adnexal/anterior, } \\
\text { posterior, and neuroophthalmic } \\
\text { lesions }\end{array}$ & \\
\hline Better than or $6 / 12$ & $\begin{array}{c}22 \\
(36.7 \%)\end{array}$ & $\begin{array}{c}3 \\
(5 \%)\end{array}$ & $\begin{array}{c}2 \\
(3.3 \%)\end{array}$ & $\begin{array}{c}3 \\
(5 \%)\end{array}$ & $30(50 \%)$ \\
\hline $6 / 18$ to $6 / 60$ & $\begin{array}{c}6 \\
(10 \%)\end{array}$ & $\begin{array}{c}7 \\
(11.7 \%)\end{array}$ & $\begin{array}{c}2 \\
(3.3 \%)\end{array}$ & - & $15(25 \%)$ \\
\hline Worse than $6 / 60$ & $\begin{array}{c}1 \\
(1.7 \%)\end{array}$ & $\begin{array}{c}6 \\
(10 \%)\end{array}$ & $\begin{array}{c}1 \\
(1.7 \%)\end{array}$ & $\begin{array}{c}7 \\
(11.7 \%)\end{array}$ & $15(25 \%)$ \\
\hline Total & $\begin{array}{c}29 \\
(48.3 \%)\end{array}$ & $\begin{array}{c}16 \\
(26.7 \%)\end{array}$ & $\begin{array}{c}5 \\
(8.3 \%)\end{array}$ & $\begin{array}{c}10 \\
(16.7 \%)\end{array}$ & 60 \\
\hline
\end{tabular}

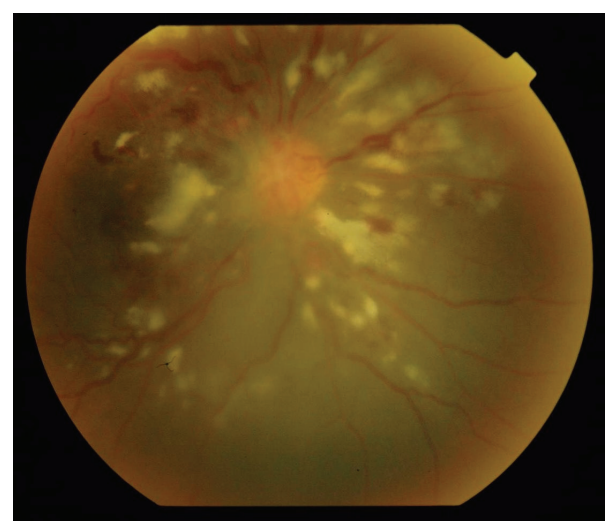

FIGURE 4: Cytomegalovirus retinitis.

CD4-count: 183 cells $/ \mathrm{mm}^{3}$ ). None of the anterior segment lesions had mean CD4-count less than 100 cells $/ \mathrm{mm}^{3}$. The mean CD4-count of patients with posterior segment lesions like CMV retinitis $\left(93.8 \mathrm{cells} / \mathrm{mm}^{3}\right)$, retinal detachment $\left(74.7 \mathrm{cells} / \mathrm{mm}^{3}\right)$, tuberculous chorioretinitis $\left(96\right.$ cells $\left./ \mathrm{mm}^{3}\right)$, and ARN $\left(64\right.$ cells $\left./ \mathrm{mm}^{3}\right)$ was less than 100 cells $/ \mathrm{mm}^{3}$. Papilledema, the most common neuroophthalmic lesion, had mean CD4-count of 134 cells $/ \mathrm{mm}^{3}$.

Out of total 27 anterior segment lesions, more than half (59.3\%) had CD4-count of more than $200 \mathrm{cells} / \mathrm{mm}^{3}$ and $22.2 \%$ lesions had CD4-count between 100 and 200 cells $/ \mathrm{mm}^{3}$ while $18.5 \%$ had CD4-count less than 100 cells $/ \mathrm{mm}^{3}$ (Table 6). By applying chi-square test, no significant association was found between the anterior segment ocular lesions and low CD4-count (CD4-count less than 100 cells $/ \mathrm{mm}^{3}$ ) of patients $(P>0.05)$. Out of total 25 posterior segment lesions, $44 \%$ of lesions were found in patients with CD4-count less than

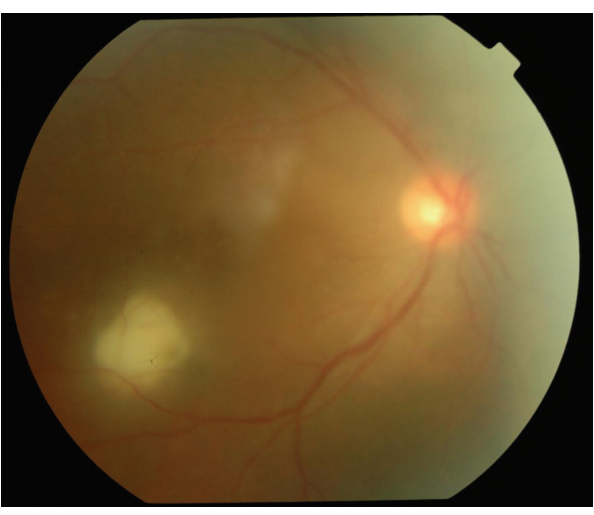

Figure 5: Active toxoplasmic retinochoroiditis.

100 cells $/ \mathrm{mm}^{3}$ while $28 \%$ of lesions were found in patients with CD4-count between 100 and 200 cells $/ \mathrm{mm}^{3}$ and more than $200 \mathrm{cell} / \mathrm{mm}^{3}$ each. There is a significant association between posterior segment ocular lesions and CD4-count $(P<0.05)$. No significant association was found between neuroophthalmic lesions and CD4-count of patients $(P>$ 0.05).

\section{Discussion}

A total of $40 \mathrm{HIV}$-positive patients reporting ocular complaints were recruited in the study and examined. Male-tofemale ratio was $1.1: 1$ with males comprising $52.5 \%$ of cases which is less than $61 \%$ reflected from the national statistics of HIV population [3]. Studies related to ocular manifestations of HIV carried out at various other centers like those done by Ebana Mvogo et al. and Assefa et al. also showed slight male preponderance as seen in our study $[4,5]$. 
TABLE 6: Association between ocular lesions and CD4-count.

\begin{tabular}{|c|c|c|c|c|}
\hline \multirow{2}{*}{ Ocular lesions } & \multicolumn{3}{|c|}{ CD4-count $\left(\right.$ cells $\left./ \mathrm{mm}^{3}\right)$} & \multirow{2}{*}{ Total } \\
\hline & $<100$ & $100-200$ & $>200$ & \\
\hline \multicolumn{5}{|c|}{ Anterior segment $(n=27)$} \\
\hline Anterior uveitis & $2(7.4 \%)$ & $2(7.4 \%)$ & $1(3.7 \%)$ & $5(18.5 \%)$ \\
\hline Molluscum contagiosum & $2(7.4 \%)$ & - & $2(7.4 \%)$ & $4(14.8 \%)$ \\
\hline Viral keratitis & - & $1(3.7 \%)$ & $3(11.1 \%)$ & $4(14.8 \%)$ \\
\hline Blepharitis & $1(3.7 \%)$ & - & $3(11.1 \%)$ & $4(14.8 \%)$ \\
\hline Herpes zoster Ophthalmicus & - & $1(3.7 \%)$ & $1(3.7 \%)$ & $2(7.4 \%)$ \\
\hline Dry eye & - & $1(3.7 \%)$ & $2(7.4 \%)$ & $3(11.1 \%)$ \\
\hline Giant papillary Conjunctivitis & - & - & $2(7.4 \%)$ & $2(7.4 \%)$ \\
\hline OSSN & - & - & $2(7.4 \%)$ & $2(7.4 \%)$ \\
\hline SJS & - & $1(3.7 \%)$ & - & $1(3.7 \%)$ \\
\hline Total & $5(18.5 \%)$ & $6(22.2 \%)$ & $16(59.3 \%)$ & 27 \\
\hline \multicolumn{5}{|c|}{ Posterior segment $(n=25)$} \\
\hline HIV retinopathy & $2(8 \%)$ & $2(8 \%)$ & $3(12 \%)$ & $7(28 \%)$ \\
\hline CMV retinitis & $4(16 \%)$ & $1(4 \%)$ & - & $5(20 \%)$ \\
\hline Toxoplasma retinochoroiditis & - & $2(8 \%)$ & $1(4 \%)$ & $3(12 \%)$ \\
\hline Retinal detachment & $3(12 \%)$ & - & - & $3(12 \%)$ \\
\hline Retinal vascular occlusions & - & $1(4 \%)$ & $1(4 \%)$ & $2(8 \%)$ \\
\hline Retinopathy of anaemia & - & $1(4 \%)$ & $1(4 \%)$ & $2(8 \%)$ \\
\hline Tubercular chorioretinitis & $1(4 \%)$ & - & - & $1(4 \%)$ \\
\hline $\mathrm{ARN}$ & $1(4 \%)$ & - & - & $1(4 \%)$ \\
\hline Endogenous endophthalmitis & - & - & $1(4 \%)$ & $1(4 \%)$ \\
\hline Total & $11(44 \%)$ & $7(28 \%)$ & $7(28 \%)$ & 25 \\
\hline \multicolumn{5}{|c|}{ Neuroophthalmic $(n=4)$} \\
\hline Papilledema & $1(25 \%)$ & - & $1(25 \%)$ & $2(50 \%)$ \\
\hline Optic neuritis & - & - & $1(25 \%)$ & $1(25 \%)$ \\
\hline 3rd cranial nerve palsy & - & - & $1(25 \%)$ & $1(25 \%)$ \\
\hline Total & $1(25 \%)$ & $\mathbf{0}$ & $3(75 \%)$ & 4 \\
\hline
\end{tabular}

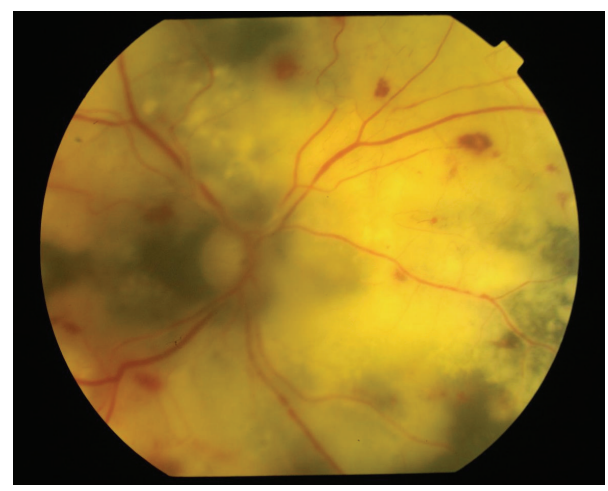

Figure 6: Acute retinal necrosis.

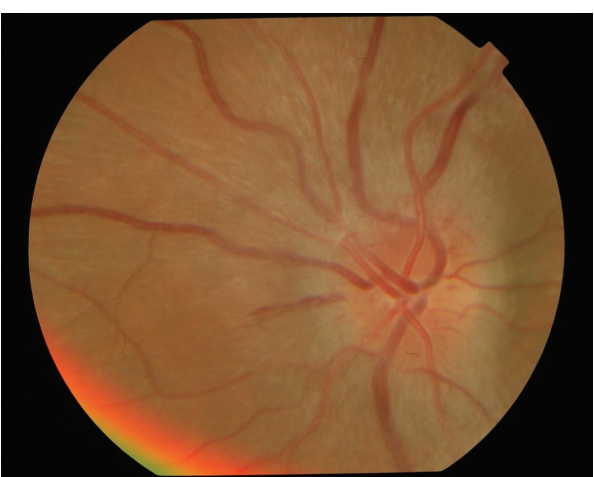

Figure 7: Optic neuritis in the right eye.
In our study, $42.5 \%$ of patients were in the age group of 21-40 years which is less than 55\% recorded by Biswas et al. in the published series of $100 \mathrm{HIV}$-positive patients with ocular manifestations from India [6]. This can be explained by the absence of HAART at the time the latter study was conducted and hence shorter life span of the patients then. The percentage distribution of patients according to age in our study was $10 \%$ in pediatric age group (up to 12 years of age), $72.5 \%$ among adults (20 to 50 years of age), and $17.5 \%$ among those above 50 years of age. This is also seen in the national statistics of $\mathrm{HIV}$-infected population (4\% among children below the age of 15 years, $83 \%$ among adults, and $13 \%$ among those aged over 50 years) [3]. In the present study, $75 \%$ belonged to the economically productive age group of $20-50$ years. This needs emphasis as the morbidity of these patients has a considerable impact on the economy of their family. 
4.1. Anterior Segment Findings. In our study, 65\% of cases had anterior segment manifestations. Similar percentage of anterior segment involvement cases were reported by Assefa et al. [5].

Anterior uveitis (12.5\%) was the most common anterior segment finding. Sudharshan et al. in their recent work of ocular lesions in 1000 consecutive HIV-positive patients in India found anterior uveitis in $16 \%$ of the patients [7]. The most likely cause of anterior uveitis was determined clinically. 2 cases of anterior uveitis were concurrent with CMV retinitis which was most probably because of the immune recovery rather than the CMV disease process itself as anterior uveitis is very rare because of CMV retinitis. 1 patient had "spill-over" anterior uveitis subsequent to toxoplasma retinochoroiditis. Another patient developed immune recovery uveitis characterized by severe anterior uveitis and vitritis along with marked diminution of vision. She was recently started (3 months back) on HAART when her CD4-count was 215 cells $/ \mathrm{mm}^{3}$ and had now improved to 496 cells $/ \mathrm{mm}^{3}$.

Molluscum contagiosum affects up to $5 \%$ of the HIVinfected patients [8]. Children account for $90 \%$ of molluscum contagiosum episodes [9]. Out of the 4 patients with molluscum contagiosum in our study, 2 were of pediatric age group. A cross-sectional hospital based study in Uganda showed that over $10 \%$ of pediatric HIV patients had molluscum contagiosum [10].

Herpes zoster ophthalmicus (HZO) and viral keratitis were found in $5 \%$ and $10 \%$ patients, respectively. This was similar to findings reported by Ndoye et al. and Ebana Mvogo et al. $[4,11]$. However Biswas et al. and Msosa and Kollmann reported the prevalence of $\mathrm{HZO}$ as $0.8 \%$ and $1 \%$, respectively $[6,12]$. However, it is difficult to draw firm conclusions about these differences as study populations have differed with regard to levels of immunodeficiency, ART exposure, and methods of case ascertainment.

OSSN was found in $2(5 \%)$ of the study patients and both of them were below the age of 50 years. HIV-induced immunosuppression resulting in reduction in the effectiveness of the immune surveillance system has already been proven to be a risk factor for squamous cell carcinoma of the conjunctiva in a case control study in Rwanda by Kestelyn et al. [13]. There was not even a single case of Kaposi's sarcoma in our study as was the case in many other Indian studies. This may possibly be due to the rarity of the human herpes virus 8 in the Indian subcontinent and human herpes virus 8 has been implicated in the causation of Kaposi's sarcoma $[14,15]$.

4.2. Posterior Segment Findings. Posterior segment lesions were seen in 24 patients $(60 \%)$. The most common posterior segment lesion was HIV retinopathy in $17.5 \%$ of patients. This finding correlates well with the study by Biswas et al. $(12.8 \%)$ in India but is quite less than compared to similar studies in USA (Holland et al., 53\%, and Kuppermann et al., $45 \%)$ and Africa (Kestelyn et al., 30\%) [6, 13, 16, 17]. In our series, majority of the patients were referred due to visual impairment. As HIV retinopathy alone does not cause much visual impairment, they probably remained undetected.
The most common ophthalmic opportunistic infection seen in the study was CMV retinitis (12.5\%). This is similar to frequency of CMV retinitis reported in other studies from India like those done by Gharai et al. (20\%), Pathai et al. (11.9\%), and Biswas et al. (17\%) $[6,18,19]$. However studies from Africa have reported very less frequency of CMV retinitis (around $1 \%$ or less) $[5,10,11]$. The low prevalence of CMV retinitis in countries of Africa as compared to America and Europe may not be a direct reflection of lower incidence but possibly reflects that the patients die from systemic opportunistic infections before their CD4-count falls low enough to allow development of CMV retinitis.

Ocular toxoplasmosis was the next most common ocular opportunistic infection and was seen in 3 patients (7.5\%). Sudharshan et al. in their study on 1000 consecutive HIVpositive patients in India found the frequency of ocular toxoplasmosis to be $4.1 \%$ which is similar to that found in our study [7].

Ocular tuberculosis was seen in $2.5 \%$ patients. It presented as tuberculoma and disseminated choroiditis. Although systemic tuberculosis was the commonest underlying systemic infection, ocular TB was relatively rare. The low frequency of ocular tuberculosis in our study may be due to the inclusion of HIV-positive patients with ocular complaints as asymptomatic choroidal tubercles are among the commonest manifestations of ocular TB in HIV.

Two patients (5\%) had retinal vascular occlusions. One patient $(2.5 \%)$ presented with central retinal artery occlusion along with 3 rd cranial nerve palsy. Cases have been reported in literature of isolated cranial nerve palsy and vascular occlusions in HIV patients but are relatively rare, arterial occlusions being very rare $[20,21]$.

One patient presented with anterior uveitis in both eyes and fundus showed large granular areas of retinal whitening along with vitritis and generalized retinal vasculitis suggestive of ARN. Pfaffl et al. reported ARN in 4 patients out of 538 HIV-positive patients they followed up for 5 years [22]. Batisse et al. inferred from their study of 26 patients of ARN in HIV-positive individuals that ARN is a late event in the course of immunosuppression (CD4-count $<100$ cells $/ \mathrm{mm}^{3}$ ) [23]. This was also highlighted in our patient whose CD4count was 64 cells $/ \mathrm{mm}^{3}$ and duration since diagnosis of HIV was 8 years.

4.3. Neuroophthalmic Lesions. In the study, $10 \%$ (4 patients) of total cases had neuroophthalmic lesions. This frequency of neuroophthalmic manifestations was similar to that reported by Assefa et al. (9.6\%), Sudharshan et al. (8.9\%), and Biswas et al. (9.3\%) [5, 7, 24].

4.4. CD4-Count Association. There was no significant association between anterior segment lesions and CD4-count of the patients. In general, the CD4-count in majority of cases $(59.3 \%)$ of anterior segment lesions was more than 200 cells $/ \mathrm{mm}^{3}$. Few patients of anterior segment lesions which had CD4-count less than 100 cells $/ \mathrm{mm}^{3}$ also had concurrent posterior segment lesion. The CD4-count distribution of various adnexal and anterior segment lesions is 
nearly similar to earlier studies by Ndoye et al., Cunningham Jr. and Margolis, and Bekele et al. [11, 25, 26].

Posterior segment lesions showed significant association with low CD4-count. Most of the posterior segment lesions (72\%) had CD4-count less than 200 cells $/ \mathrm{mm}^{3}$. All the active cases of CMV retinitis had CD4-count less than 100 cells $/ \mathrm{mm}^{3}$ as already highlighted by Jabs et al. in their study way back in 1989 [27]. 66.7\% patients of toxoplasma retinochoroiditis had CD4-count between 101 and 200 cells $/ \mathrm{mm}^{3}$. This finding shows that opportunistic ocular infection due to toxoplasma gondii increases as immunity of patient decreases, especially when CD4-cell count becomes less than $200 \mathrm{cell} / \mathrm{mm}^{3}$ as reported in earlier studies [28]. All cases of retinal detachment had CD4count less than $100 \mathrm{cell} / \mathrm{mm}^{3}$. This may be because retinal detachment was seen as complication of CMV retinitis and tuberculous retinochoroiditis which generally occur in low CD4-count. There was no significant association between neuroophthalmic lesions and CD4-count of the patient. Like in studies by Bekele et al. and Kumar et al., in our study too neuroophthalmic lesions were seen in the entire spectrum of CD4-count $[26,29]$.

\section{Conclusions}

Ocular manifestations in HIV/AIDS affect mainly the economically productive and socially important age group of 20 to 50 years with slight male preponderance. HIV retinopathy was the most common ocular lesion encountered in our study with mild visual deterioration and good immune status. CMV retinitis was the next common lesion with severe degree of visual impairment and poor immune status. Anterior uveitis was the most common anterior segment manifestation. Systemic tuberculosis was the most common coexistent systemic disease in our study. The percentage of posterior segment ocular manifestations of HIV increased as the CD4-count of HIV-positive patients decreased. The severity of ocular manifestations in HIV/AIDS with respect to visual impairment was higher in patients with low CD4counts. Hence the patients with serological diagnosis of HIV should be examined for ocular involvement and correlated to CD4-count for treatment and better visual prognosis.

$\begin{array}{ll}\text { Abbreviations } \\ \text { AIDS: } & \text { Acquired immunodeficiency syndrome } \\ \text { ARN: } & \text { Acute retinal necrosis } \\ \text { ART: } & \text { Antiretroviral therapy } \\ \text { CMV: } & \text { Cytomegalovirus } \\ \text { DNA: } & \text { Deoxyribonucleic acid } \\ \text { HAART: } & \text { Highly active antiretroviral therapy } \\ \text { HIV: } & \text { Human immunodeficiency virus } \\ \text { HZO: } & \text { Herpes zoster ophthalmicus } \\ \text { MRI: } & \text { Magnetic resonance imaging } \\ \text { NACO: } & \text { National AIDS Control Organisation } \\ \text { PCR: } & \text { Polymerase chain reaction } \\ \text { TB: } & \text { Tuberculosis. }\end{array}$

\section{Consent}

The authors obtained consent form from the patient.

\section{Conflict of Interests}

The authors declare that there is no conflict of interests regarding the publication of this paper.

\section{Acknowledgments}

Dr. Pratik Gogri acknowledges with a deep sense of reverence his gratitude towards the staff of ART Center of Pravara Rural Hospital, Loni, for their undiluted cooperation throughout the study. He is also grateful to Dr. Mrs. Surekha Bangal, M.S. (ophthalmology), Professor and Head, Department of Ophthalmology, for her valuable guidance and suggestions. He would like to thank Dr. Amol Wankhede (vitreoretinal surgeon, Associate Professor, ophthalmology), Dr. Neeta Misra (Professor, ophthalmology), Dr. Kishor Badhe (Professor, ophthalmology), Dr. Shubhangi Nigwekar (Professor, ophthalmology), Dr. Waman Chavan (Associate Professor, ophthalmology), and all his colleagues from the Department of Ophthalmology, Pravara Rural Hospital, Loni, for their support.

\section{References}

[1] A. S. Fauci, “Twenty-five years of HIV/AIDS," Science, vol. 313, no. 5786, p. 409, 2006.

[2] W. G. Hodge, S. R. Seiff, and T. P. Margolis, "Ocular opportunistic infection incidences among patients who are HIV positive compared to patients who are HIV negative," Ophthalmology, vol. 105, no. 5, pp. 895-900, 1998.

[3] A. Pandey, D. Sahu, T. Bakkali et al., "Estimate of HIV prevalence and number of people living with HIV in India 20082009," BMJ Open, vol. 2, no. 5, Article ID e000926, 2012.

[4] C. Ebana Mvogo, A. Ellong, A. L. Bella, H. Luma, and H. Achu Joko, "Ocular complications of HIV/AIDS in Cameroon: is there is any correlation with the level of CD4 lymphocytes count?", Bulletin de la Société belge d’ophtalmologie, no. 305, pp. 7-12, 2007.

[5] Y. Assefa, G. Yohannes, and A. Melese, "Ocular manifestations of HIV/AIDS patients in Gondar University Hospital, north west Ethiopia," The Ethiopian Journal of Health Development, vol. 20, no. 3, pp. 166-169, 2006.

[6] J. Biswas, H. N. Madhavan, A. E. George, N. Kumarasamy, and S. Solomon, "Ocular lesions associated with HIV infection in India: a series of 100 consecutive patients evaluated at a referral center," American Journal of Ophthalmology, vol. 129, no. 1, pp. 9-15, 2000.

[7] S. Sudharshan, S. Kaleemunnisha, A. A. Banu et al., "Ocular lesions in 1,000 consecutive HIV-positive patients in India: a long-term study," Journal of Ophthalmic Inflammation and Infection, vol. 3, article 2, 2013.

[8] B. H. Jeng, G. N. Holland, C. Y. Lowder, W. F. Deegan III, M. B. Raizman, and D. M. Meisler, "Anterior segment and external ocular disorders associated with human immunodeficiency virus disease," Survey of Ophthalmology, vol. 52, no. 4, pp. 329368, 2007.

[9] R. S. Pannell, D. M. Fleming, and K. W. Cross, "The incidence of molluscum contagiosum, scabies and lichen planus," Epidemiology and Infection, vol. 133, no. 6, pp. 985-991, 2005. 
[10] E. Ikoona, I. Kalyesubula, and M. Kawuma, "Ocular manifestations in paediatric HIV/AIDS patients in Mulago Hospital, Uganda," African Health Sciences, vol. 3, no. 2, pp. 83-86, 2003.

[11] N. B. Ndoye, P. S. Sow, E. A. Ba, M. R. Ndiaye, A. Wade, and A. M. Coll-Seck, "Ocular manifestations of AIDS in Dakar," Dakar Medical, vol. 38, no. 1, pp. 97-100, 1993.

[12] A. H. Msosa and K. H. M. Kollmann, Prevalence, complications and associations of herpes zoster ophthalmicus at Kenyatta National Hospital [MEd Dissertation], University of Nairobi, 1999.

[13] P. Kestelyn, P. van de Perre, D. Rouvroy et al., "A prospective study of the ophthalmologic findings in the acquired immune deficiency syndrome in Africa," The American Journal of Ophthalmology, vol. 100, no. 2, pp. 230-238, 1985.

[14] P. S. Moore and Y. Chang, "Detection of herpesvirus-like DNA sequences in Kaposi's sarcoma in patients with and those without HIV infection," The New England Journal of Medicine, vol. 332, no. 18, pp. 1181-1185, 1995.

[15] D. Ablashi, L. Chatlynne, H. Cooper et al., "Seroprevalence of human herpesvirus-8 (HHV-8) in countries of Southeast Asia compared to the USA, the Caribbean and Africa," British Journal of Cancer, vol. 81, no. 5, pp. 893-897, 1999.

[16] G. N. Holland, J. S. Pepose, T. H. Pettit, M. S. Gottlieb, R. D. Yee, and R. Y. Foos, "Acquired immune deficiency syndrome. Ocular manifestations," Ophthalmology, vol. 90, no. 8, pp. 859873, 1983.

[17] B. D. Kuppermann, J. G. Petty, D. D. Richman et al., "Correlation between $\mathrm{CD} 4+$ counts and prevalence of cytomegalovirus retinitis and human immunodeficiency virus-related noninfectious retinal vasculopathy in patients with acquired immunodeficiency syndrome," American Journal of Ophthalmology, vol. 115, no. 5, pp. 575-582, 1993.

[18] S. Gharai, P. Venkatesh, S. Garg, S. K. Sharma, and R. Vohra, "Ophthalmic manifestations of HIV infections in India in the era of HAART: analysis of 100 consecutive patients evaluated at a tertiary eye care center in India," Ophthalmic Epidemiology, vol. 15, no. 4, pp. 264-271, 2008.

[19] S. Pathai, A. Deshpande, C. Gilbert, and S. D. Lawn, "Prevalence of HIV-associated ophthalmic disease among patients enrolling for antiretroviral treatment in India: a cross-sectional study," BMC Infectious Diseases, vol. 9, article 158, 2009.

[20] M. D. Conway, P. Tong, and R. J. Olk, "Branch retinal artery occlusion (BRAO) combined with branch retinal vein occlusion (BRVO) and optic disc neovascularization associated with HIV and CMV retinitis," International Ophthalmology, vol. 19, no. 4, pp. 249-252, 1995.

[21] A. Moulignier, L. Laloum, E. Chauveau, O. Gout, and W. Rozenbaum, "HIV-1 related ischaemic trochlear nerve palsy," Journal of Neurology, vol. 250, no. 1, pp. 108-109, 2003.

[22] W. Pfaffl, E.-M. Fabricius, K. Scheidegger, and M. Brommer, "Acute retinal necrosis (ARN) and HIV infection," Fortschritte der Ophthalmologie, vol. 88, no. 6, pp. 705-711, 1991.

[23] D. Batisse, M. Eliaszewicz, L. Zazoun, M. Baudrimont, G. Pialoux, and B. Dupont, "Acute retinal necrosis in the course of AIDS: study of 26 cases," AIDS, vol. 10, no. 1, pp. 55-60, 1996.

[24] J. Biswas, L. Therese, N. Kumarasamy, S. Solomon, and P. Yesudian, "Lid abscess with extensive molluscum contagiosum in a patient with acquired immunodeficiency syndrome," Indian Journal of Ophthalmology, vol. 45, no. 4, pp. 234-236, 1997.

[25] E. T. Cunningham Jr. and T. P. Margolis, "Ocular manifestations of HIV infection," The New England Journal of Medicine, vol. 339, no. 4, pp. 236-244, 1998.
[26] S. Bekele, Y. Gelaw, and F. Tessema, "Ocular manifestation of HIV/AIDS and correlation with CD4+ cells count among adult HIV/AIDS patients in Jimma town, Ethiopia: a cross sectional study," BMC Ophthalmology, vol. 13, no. 1, article 20, 2013.

[27] D. A. Jabs, W. R. Green, R. Fox, B. F. Polk, and J. G. Bartlett, "Ocular manifestations of acquired immune deficiency syndrome," Ophthalmology, vol. 96, no. 7, pp. 1092-1099, 1989.

[28] B. J. Turner, F. M. Hecht, and R. B. Ismail, "CD4+ T-lymphocyte measures in the treatment of individuals infected with human immunodeficiency virus type: a review for clinical practitioners," Archives of Internal Medicine, vol. 154, no. 14, pp. 1561-1573, 1994.

[29] P. Kumar, D. P. Vats, S. Mishra et al., "CD4 counts: a strong indicator of retinal and ocular lesions in HIV disease," Medical Journal Armed Forces India, vol. 67, no. 4, pp. 354-357, 2011. 


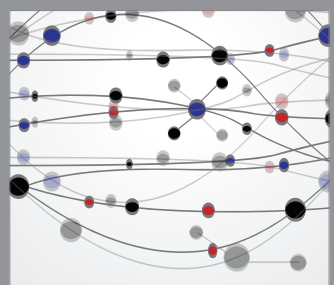

The Scientific World Journal
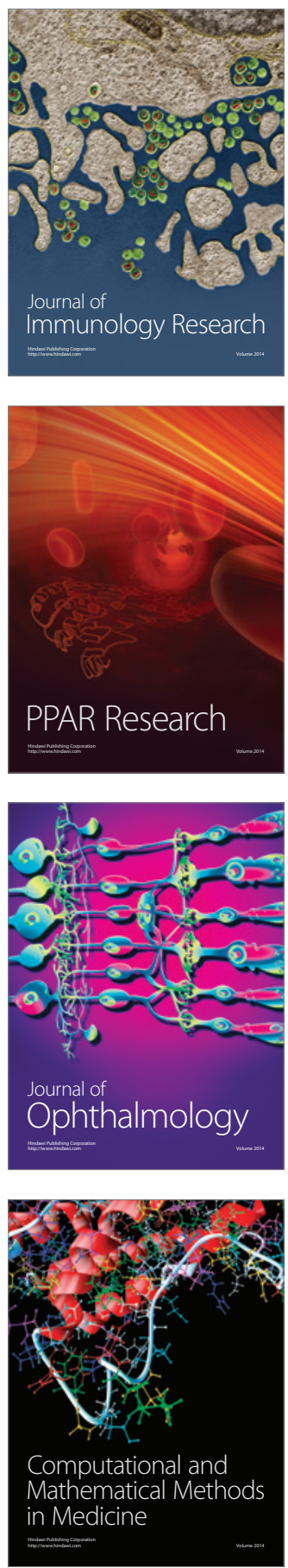

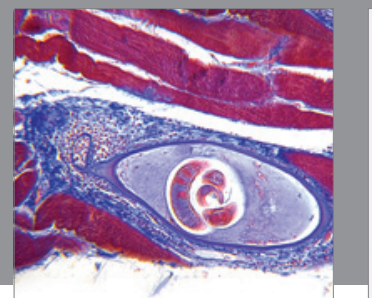

Gastroenterology

Research and Practice
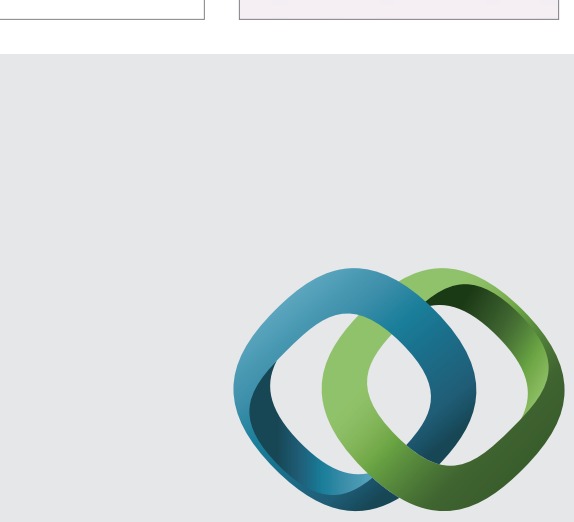

\section{Hindawi}

Submit your manuscripts at

http://www.hindawi.com
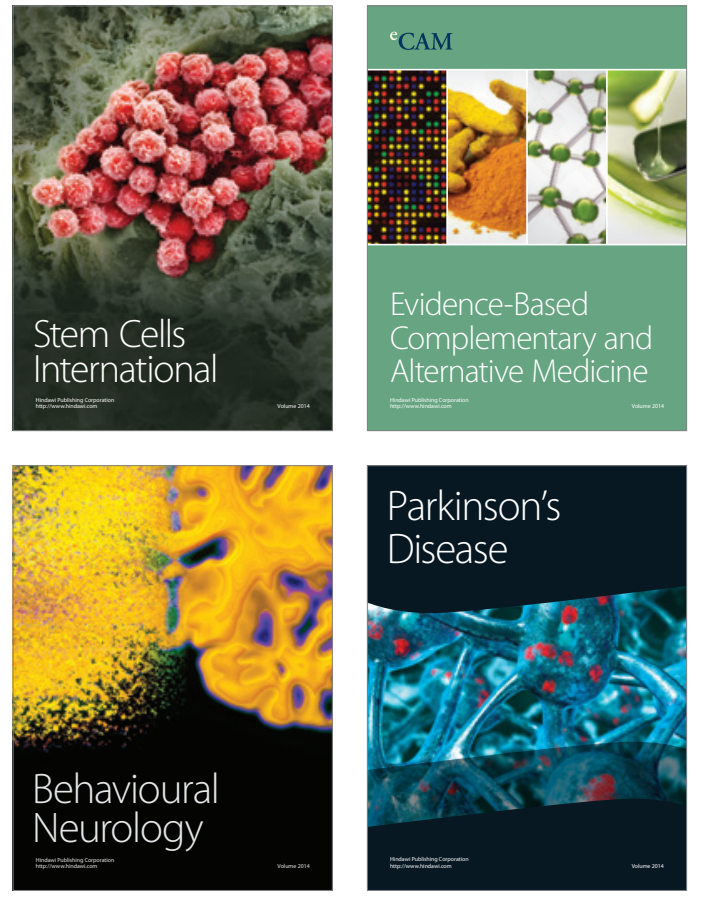
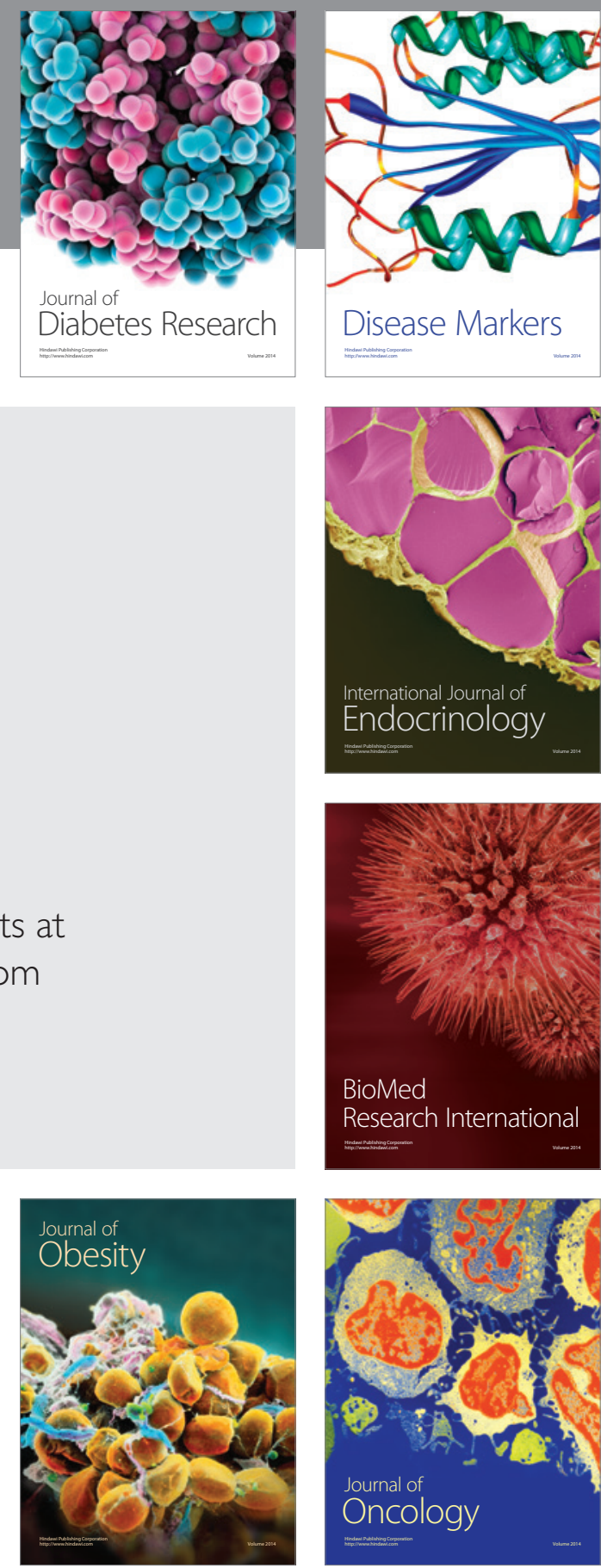

Disease Markers
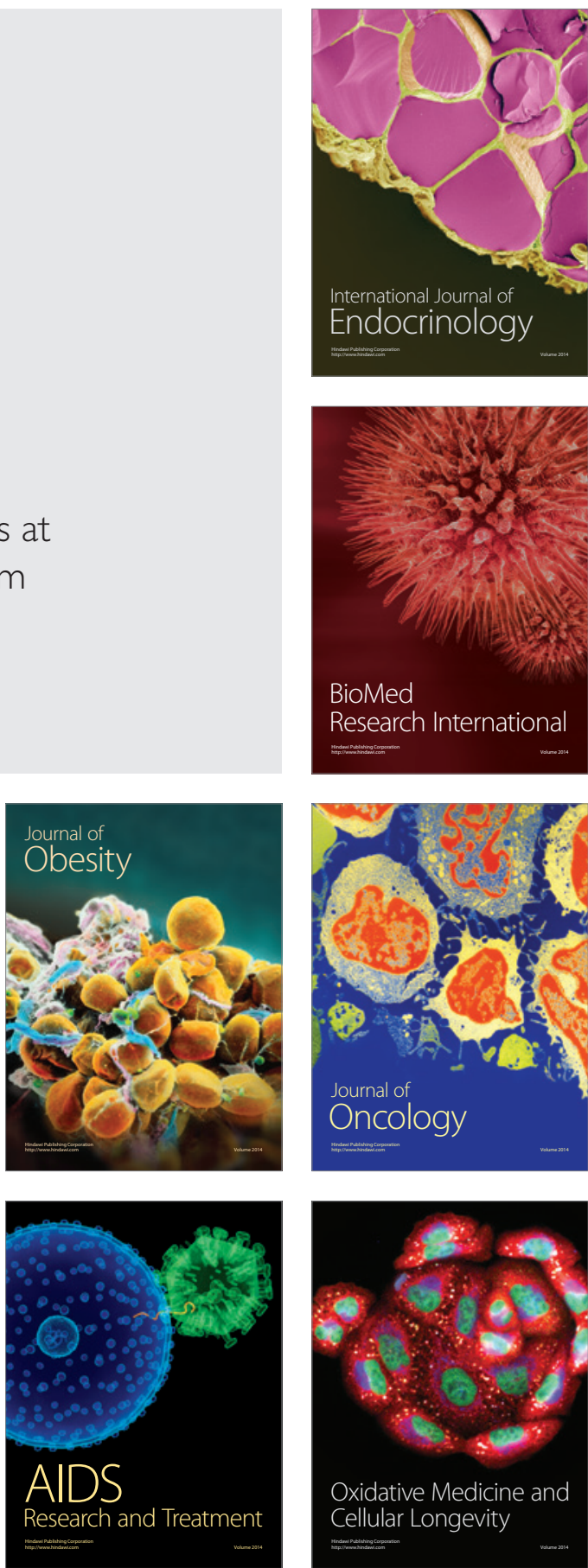